
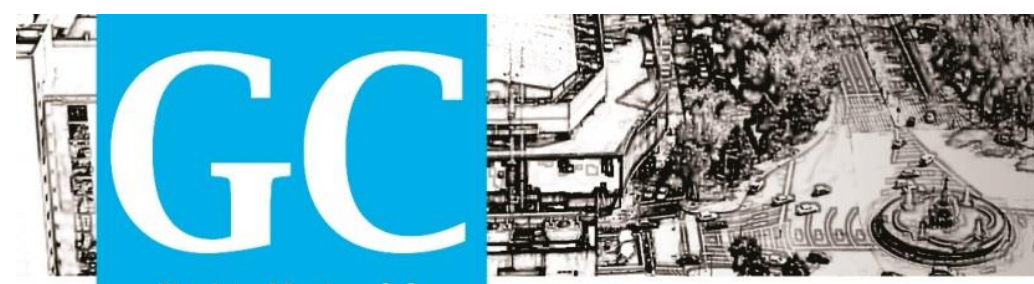

\title{
CEMITÉRIO MUNICIPAL JARDIM BOTUCATU / SÃO PAULO
}

\author{
Luís Augusto Gomes Rocha'
}

Alcides Lopes Leão ${ }^{2}$

\section{Ivo Francisco Barbosa ${ }^{3}$}

RESUMO: A expansão urbana acarreta a necessidade de mitigações ambientais, em que um planejamento do uso do solo bem como seu processo de ocupação traz a necessidade também de estudos para viabilizar tais ações. Nesse processo de expansão, os cemitérios necessitam de maior atenção, já que evidenciaram indícios de contaminações no solo e em fontes de água próximas. Atualmente, o Conselho Nacional de Meio Ambiente possui duas resoluções que discorrem sobre os aspectos construtivos visando controlar os resíduos existentes, tais como o Liquame da Coliquação (também conhecido por Necrochorume), um dos responsáveis pela contaminação do solo e aquíferos subterrâneos. Tendo esse escopo em pauta, esse trabalho exibe um estudo preliminar no Cemitério Municipal Jardim - Botucatu / São Paulo, que colaborou com informações para a execução do Estudo de Viabilidade Ambiental no local. Nesse estudo estão elencados os

\footnotetext{
${ }^{1}$ Engenheiro Florestal - Faculdade de Ciências Agronômicas - Unesp / Botucatu, lagrocha@fca.unesp.br

2 Engenheiro Agrônomo - Prof. Dr. do Dep. de Recursos Naturais, Faculdade de Ciências Agronômicas, Unesp / Botucatu, alcidesleao@fca.unesp

${ }^{3}$ Geógrafo - Universidade do Sagrado Coração - USC / Bauru, ivo fb@hotmail.com
} 


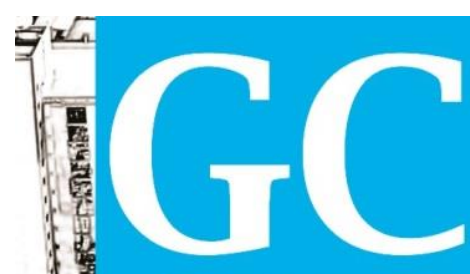

Revista Nacional de

Gerenciamento de Cidades

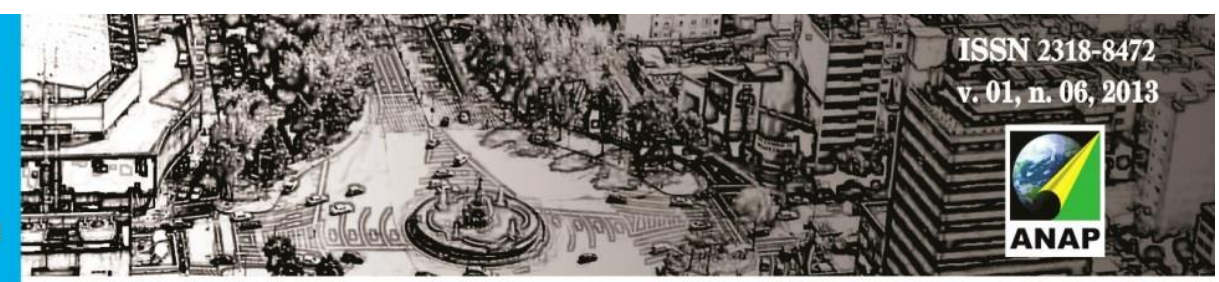

"problemas" existentes e possíveis soluções mitigadoras, buscando assim a sustentabilidade urbana.

Palavras chave: Cemitérios. Estudo de Viabilidade Ambiental. Necrochorume.

\section{INTRODUÇÃO}

A partir do final da década de 70, o gerenciamento integrado dos recursos hídricos começou a ser encarado como problema socioambiental, debatendo sobre a necessidade de gerir, ampliando inicialmente a oferta de água nas bacias hidrográficas; posteriormente, utilizando dispositivos de comando/controle como balizadores da demanda crescente de água (agricultura, aquicultura, consumo humano e indústria). Com essa demanda, manter a sustentabilidade dos recursos hídricos tornou-se um tópico de estudo das instituições públicas/privadas, buscando alternativas sustentáveis de manutenção e uso.

Segundo Kemerich (2010, apud Paiva, 2001), do total de água doce disponível, $78,1 \%$ encontram-se nas geleiras e 21,5\% correspondem aos reservatórios de águas subterrâneas. As águas superficiais são menos de $1 \%$ do total, sendo que $0,33 \%$ encontram-se nos lagos, $0,035 \%$ na atmosfera e $0,03 \%$ flui nos rios. Disposto nessa matriz, os recursos hídricos estão sob forte "pressão", o que torna futuramente as águas subterrâneas como a principal fonte de abastecimento da população.

Um grave problema para a proteção das águas subterrâneas nos centros urbanos, de acordo com Kemerich (2010), são os cemitérios, pois estes podem trazer sérias consequências ambientais. Em particular, a qualidade das águas subterrâneas é comprometida devido à infiltração e percolação das águas pluviais através dos túmulos e 


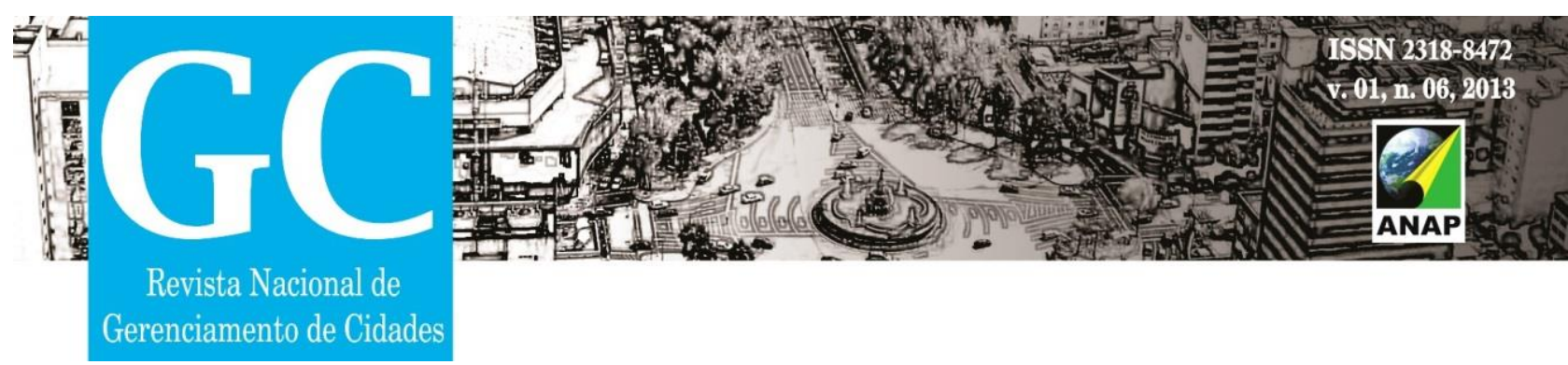

solo, o que provoca a lixiviação de uma série de compostos químicos orgânicos e inorgânicos através da zona não saturada, podendo alguns destes compostos atingir a zona saturada e, portanto, poluir o aquífero.

Segundo Macedo (2004), após o falecimento, o corpo humano começa a se transformar, e passa a ser um ecossistema de populações, formado por artrópodes, bactérias, microrganismos patogênicos destruidores de matéria orgânica e outros, podendo pôr em risco o meio ambiente e a saúde pública. O corpo humano sofre então a putrefação, que é a destruição dos tecidos por bactérias e enzimas, resultando na dissolução gradual em gases, líquidos e sais.

O processo natural da putrefação é influenciado por fatores intrínsecos (idade, constituição física e causa-mortis) e extrínsecos (temperatura, umidade, aeração, constituição mineralógica do solo e permeabilidade). Romanó (2009) comenta a contaminação que pode atingir as águas subterrâneas através do liquame. Segundo ele, o produto de coliquação é uma solução aquosa rica em sais minerais e substâncias orgânicas degradáveis, de tonalidade castanho-acinzentada, de cheiro forte e com grau variado de patogenicidade, e é liberada pelos cadáveres em putrefação.

Um paralelo pertinente seria o descrito por Pires, A. S (2008 apud Santos 2007) de que as necrópoles em muito podem se assemelhar a um aterro sanitário, já que em ambos são enterrados materiais orgânicos e inorgânicos, com um agravante para os cemitérios: a matéria orgânica ali enterrada tem a possibilidade de carregar consigo bactérias que foram, provavelmente, a causa da morte do indivíduo, podendo colocar em risco o meio ambiente e a saúde pública.

Vários estudos foram feitos em cemitérios comprovando índices de contaminação, como o de Ueda (2011), que, após desenvolver coleta de 130 amostras de terra (49 consideradas como terras "virgens" ${ }^{4}, 81$ onde haviam corpos sepultados), exibiu que a

\footnotetext{
${ }^{4}$ Locais onde não foram sepultados corpos
} 


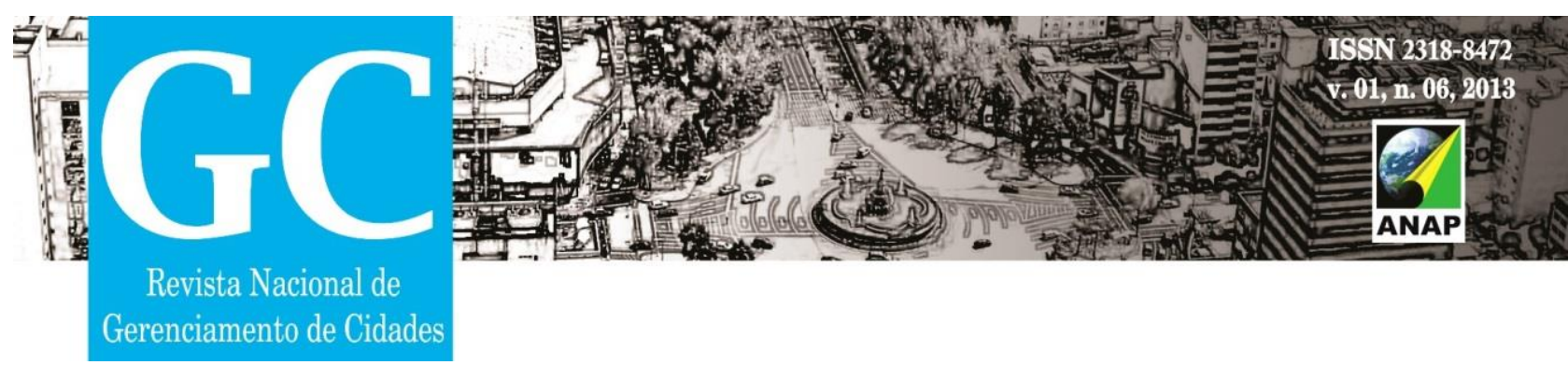

microbiota da terra dos cemitérios é composta por vários micro-organismos: cocos Gram positivos, bacilos Gram positivos, bacilos Gram negativos, bactérias anaeróbias estritas e fungos. A coleta foi desenvolvida em várias profundidades e não observou diferença entre a microbiota das terras consideradas "virgens" e das terras com corpos sepultados.

Tanto a legislação quanto o cuidado com o meio ambiente devem pautar-se na cautela preventiva, em que, para amenizar possíveis impactos causados pelos cemitérios, fez-se necessária a criação de leis e decretos específicos, os quais condicionam este tipo de empreendimento. Dentro desse escopo, um estudo preliminar foi realizado no Cemitério Municipal Jardim - Botucatu / São Paulo, onde tais informações tiveram como objetivo sediar bases para um Estudo de Viabilidade Ambiental, visando regularizar as inconformidades existentes no local.

\section{Estudo Preliminar - Inconformidades}

Com o intuito de sintetizar as informações fornecidas pelos administradores na vistoria técnica, um questionário foi aplicado para recolher informações sobre os procedimentos e problemas encontrados no local. Deste modo, um benefício em conjunto foi a possibilidade de o administrador relacionar problemas ambientais e sociais que ocorrem no local, bem como o destino dos resíduos sólidos e a existência de pragas para um futuro plano de manejo.

\section{- Deposição de resíduos}

Problema: O local em questão tem como destino os lixos de exumação, capinação e as coroas de flores. $O$ agente de apoio descreveu que a empresa responsável pela retirada dos resíduos do cemitério, ao recolhê-los, depositam-nos no mesmo caminhão, para, posteriormente, efetuar o translado até o aterro sanitário. 

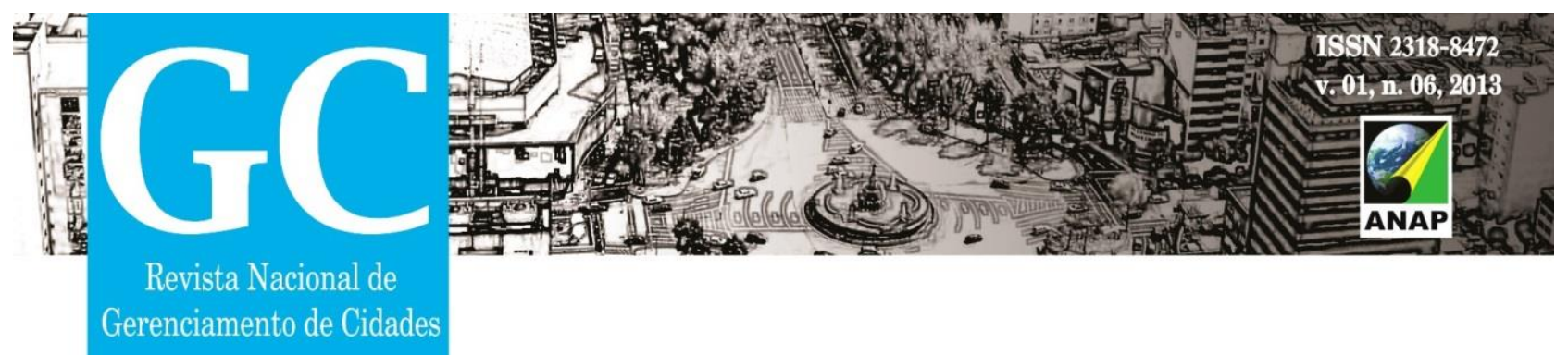

Tem-se por definição que, segundo a Norma ABNT 10.004, os resíduos nos estados sólido e semi-sólido, que são resultantes de atividades de origem industrial, doméstica, hospitalar, comercial, agrícola, de serviços e de varrição devem ter seu translado efetuado em caminhões específicos (grupo A2); o que também é afirmado pela Portaria n`358 do CONAMA (Conselho Nacional do Meio Ambiente) em seu artigo decimo sexto, correlaciona resíduos de sepultamentos em cemitérios devem ser tratados como do Grupo $A 2^{5}$. Uma vez que o procedimento para deposição é distinto. Essa inadequação exibe a necessidade de efetuar o tratamento adequado aos resíduos sólidos gerados.

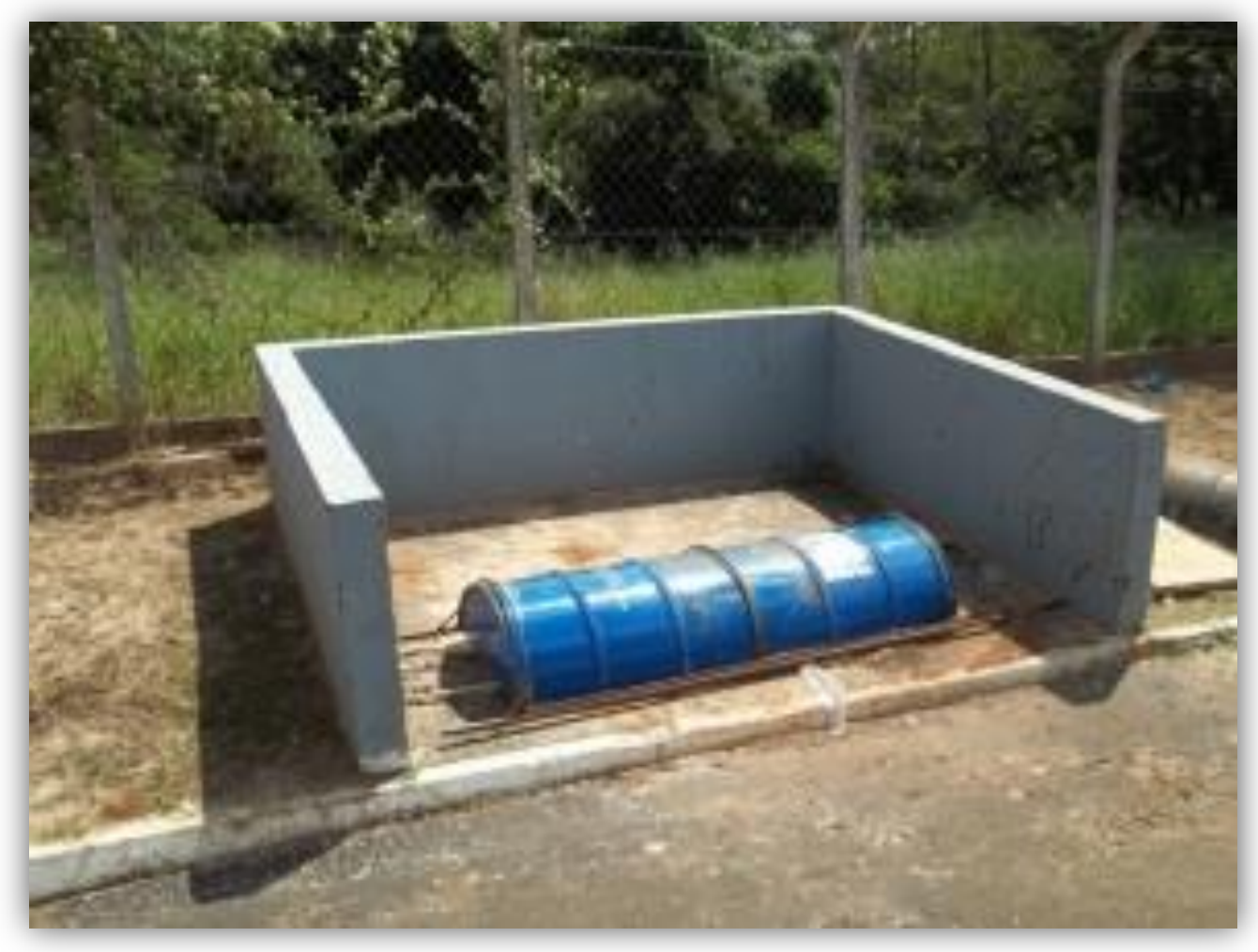

Figura 1 - Destino dos restos de exumação, capinação e coroas de flores.

\footnotetext{
5 Tais resíduos devem ser submetidos a processo de tratamento com redução de carga microbiana compatível.
} 


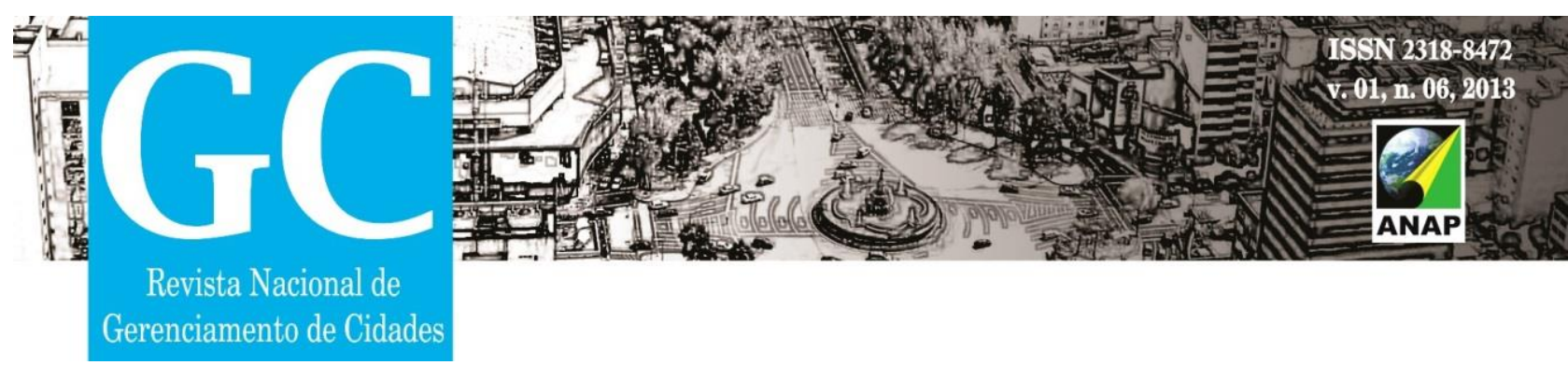

Sugestão de ação mitigadora: em cerne, deve-se respeitar a Norma Técnica L10.004 da CETESB - tópico $5^{\circ}$ subitem j:

[...] resíduos sólidos relacionados à exumação dos corpos, tais como urnas e material descartável (luvas, sacos plásticos, etc.) deverão ter, preferencialmente, o mesmo tratamento dado aos resíduos sólidos gerados pelos serviços de saúde, de acordo com a legislação vigente (Resolução CONAMA № 5, de 1993 e, no caso de incineração local, Norma CETESB E15.011). Se os resíduos sólidos forem enterrados no próprio cemitério, deverá ser usada unicamente a zona de sepultamento com recobrimento mínimo de $0,5 \mathrm{~m}$ de solo.

É pertinente adotar a descrição de Campos (2007) de

[...] não utilizar a faixa do perímetro de segurança do empreendimento para armazenar esses resíduos, nem os aterros sanitários. É preciso considerar que esses resíduos, podem ser focos de fungos e bactérias, principalmente se forem resíduos de mortos por doenças contagiosas ou violentas, bem como os restos de exumação de cadáveres submetidos a tratamentos para câncer. É importante enterrá-los ou incinera-los no próprio cemitério ou serem retirados por empresas especializadas em resíduos de serviços de saúde.

\section{- Ossuário}

Problema: a grande dificuldade de se comentar a respeito de procedimentos dentro de um cemitério é a linha tênue entre a prestação de serviços e o social/emocional envolvido. Desta maneira, a problemática envolvida no ossuário é encontrar uma forma honrosa e organizada de depositar os restos mortais. Durante o estudo, percebeu-se que grande parte dos familiares não procura executar exumação no tempo acordado. Desta forma, o Serviço Funerário Municipal de Botucatu (SFMB) executa a exumação do indivíduo em sacos mortuários (sacolas impermeabilizadas), colocando-os em um ossuário 


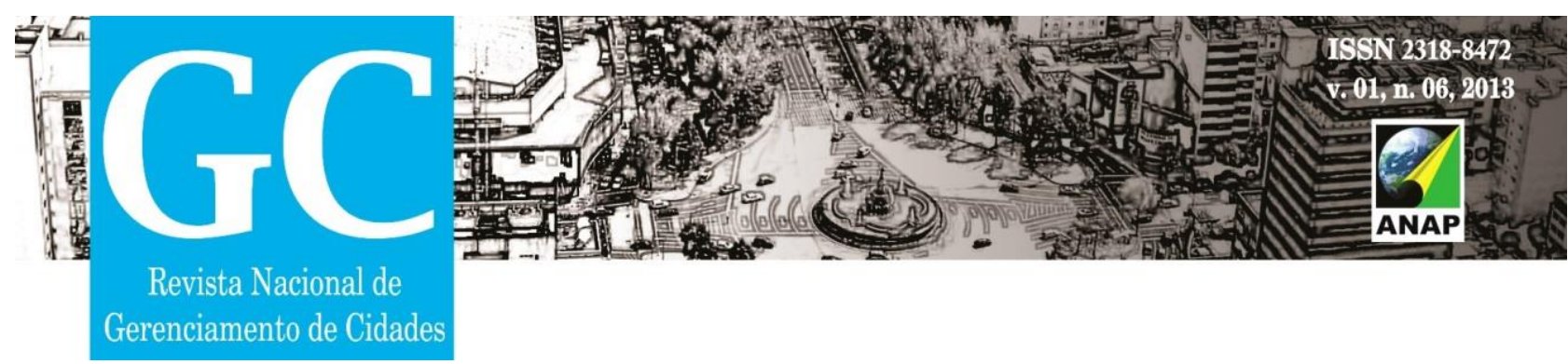

geral. Assim como já visto em outros cemitérios municipais, a contínua alocação desses sacos gera uma deposição desorganizada e a necessidade de uma ininterrupta ampliação da área destinada ao acondicionamento dessas sacolas, podendo ocorrer, como descrito pelo agente de apoio, em uma "confusão ao se procurar um indivíduo".

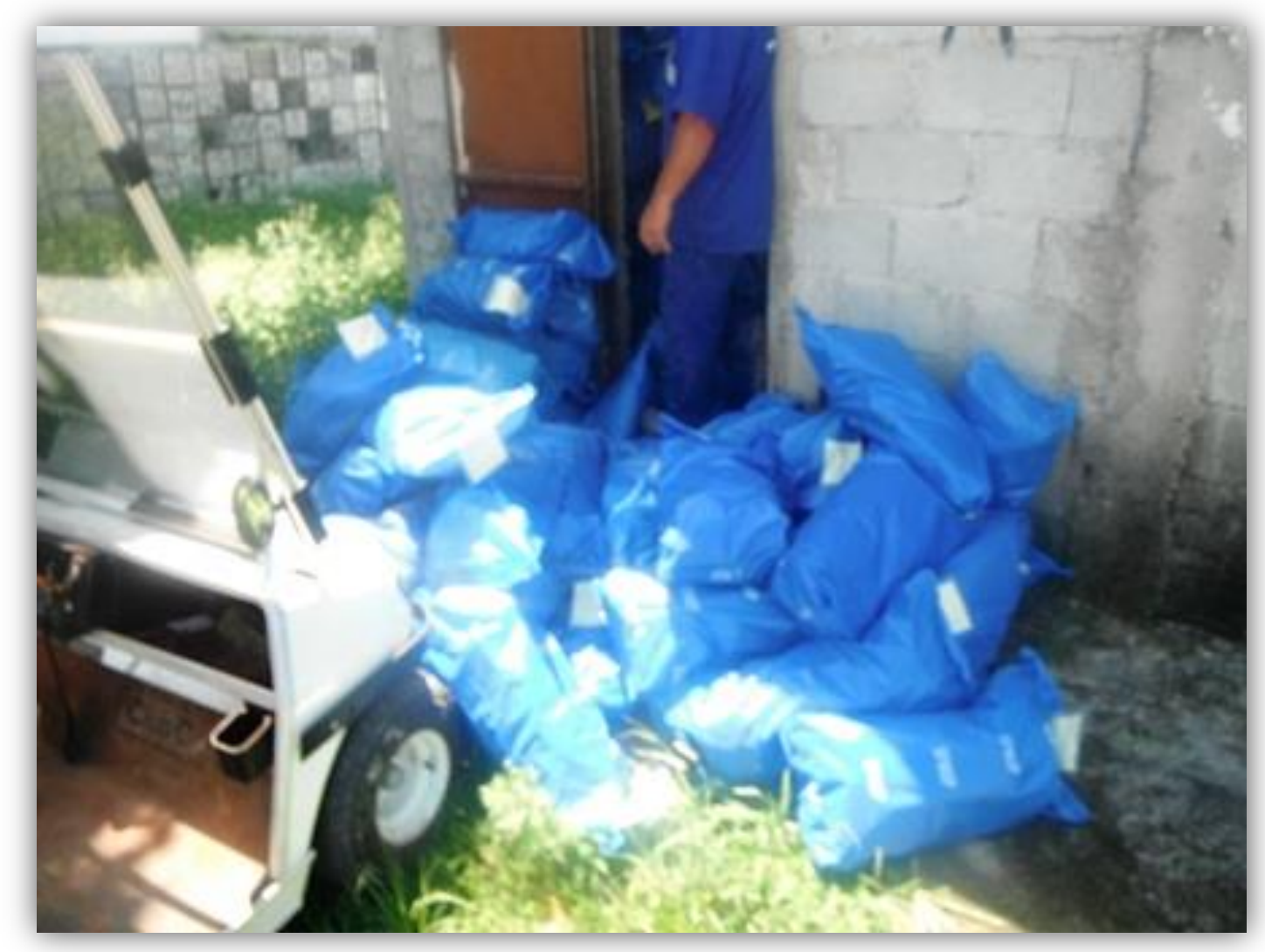

Figura 2 - Fotos do Estudo de Viabilidade Ambiental Cemitério Municipal Vila Nova Cachoerinha

Sugestão de ação mitigadora: é necessário enfatizar que o procedimento de armazenagem é uma das áreas mais tradicionais de suporte ao processo logístico, e, no caso em questão, dará apoio ao desempenho das atividades primárias, uma vez que os processos de sepultamento e exumação são interligados. 

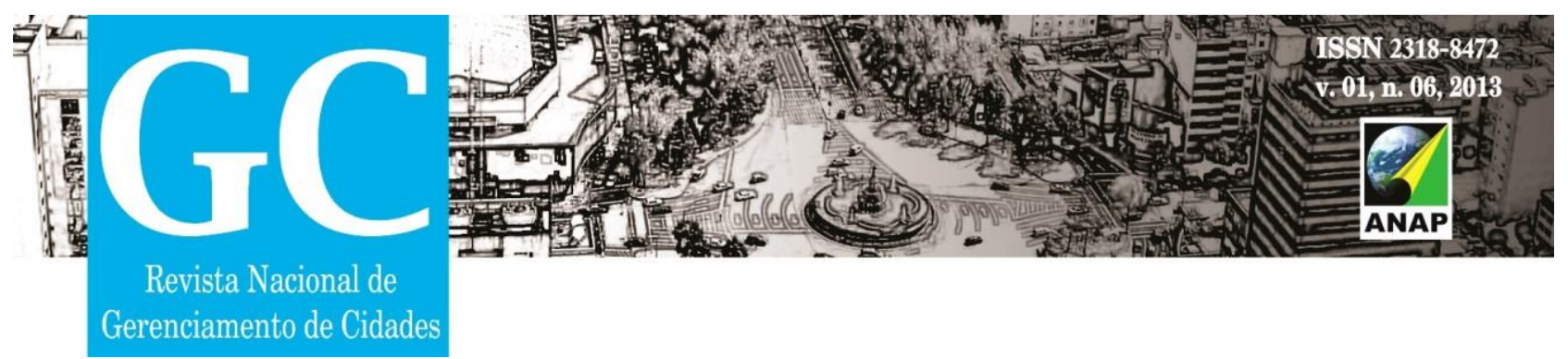

Um exemplo para solucionar a questão seria instalar prateleiras móveis ${ }^{6}$, uma vez que se necessita de acesso direto e facilidade para alocação e catalogação. A principal vantagem é o fato de oferecerem a melhor utilização do espaço disponível. As filas de prateleiras necessárias podem ser colocadas nos carros ou transportadas sobre calhas, através de um motor elétrico. Este sistema tornaria o armazenamento móvel e, em consequência, uma logística de armazenamento mais eficiente (maior capacidade de armazenamento ou um aumento econômico do espaço, para uma utilização adicional, como para urna de cinzas).

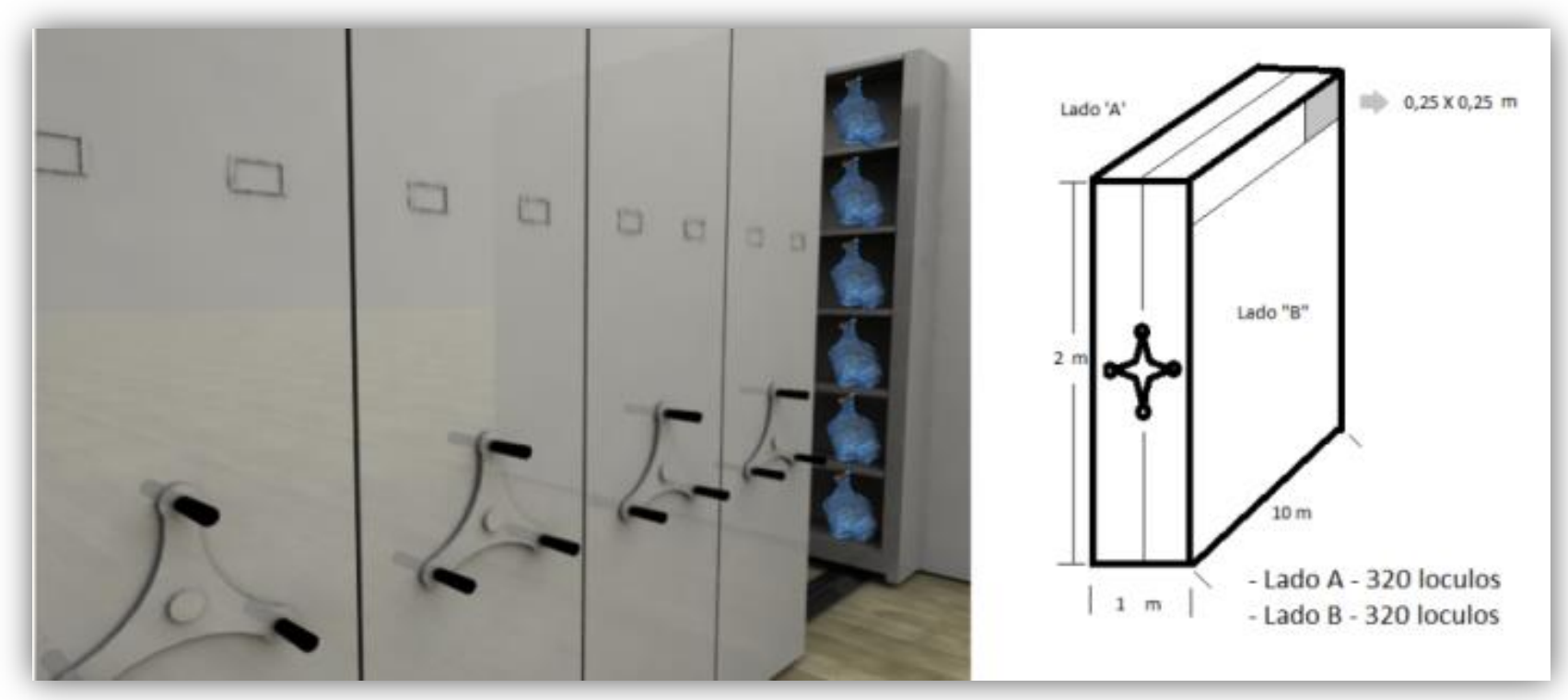

Figura 3 - Cada estante suportaria 640 lóculos em 12 m²

\section{- Vegetação Arbórea}

Problema: o plantio de espécies arbóreas no cemitério é de grande ajuda, tanto que Üçiski e Brook (1998) relataram "que plantas poderiam ser utilizadas para remover

\footnotetext{
${ }^{6}$ Referente a utilização do espaço, para o mesmo volume de artigos armazenados, os sistemas de prateleiras móveis requerem $40 \%$ menos espaço que os sistemas de prateleiras fixas.
} 


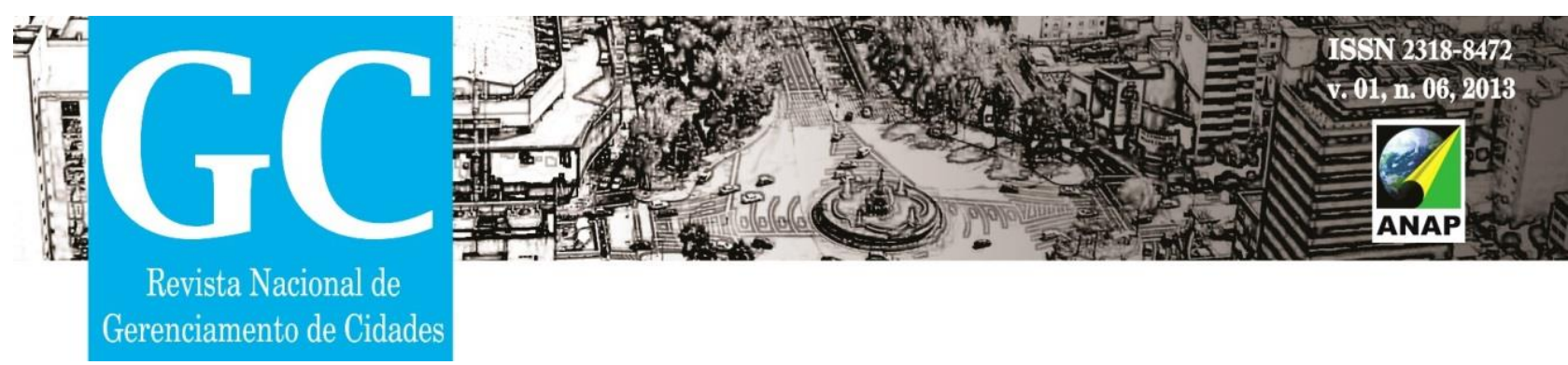

alguns vírus e bactérias do solo, pois suas raízes restringem o movimento desses microrganismos, e que o plantio de árvores e plantas deve ser incentivado ao redor" e interior dos cemitérios.

Podemos visualizar no cemitério em questão um grande número de árvores exóticas, o que vai de encontro com a recomendação da Norma Técnica L1.040 da CETESB, em seu Tópico $5^{\circ}$ subitem c, que descreve:

[...] internamente, o cemitério deverá ser contornado por uma faixa com largura mínima de $5 \mathrm{~m}$, destituída de qualquer tipo de pavimentação ou recobertura de alvenaria, destinada à implantação de uma cortina constituída por árvores e arbustos adequados, preferencialmente de essências nativas. Parte dessa faixa poderá ter $20 \%$ em sua extensão linear destinada a edifícios, sistema viário ou logradouro de uso público, desde que não contrariem a legislação vigente. Caso a faixa interna exceda este valor mínimo, em situações específicas, poderá ser permitida a construção de ossários regulamentares, sistema viário ou outras construções".

Em consonância visualizamos muitas espécies arbóreas causando problemas em jazigos, ruas e redes de drenagem, necessitando de poda ou mesmo transplante do local em questão; tal situação é orientada na mesma Norma Técnica, que descreve:

[...] no interior do cemitério, na chamada zona de enterramento ou sepultamento, é aconselhável o plantio de espécies com raízes pivotantes, a fim de evitar invasões de jazigos, destruição do piso e túmulos ou danos às redes de água, de esgoto e drenagem. 


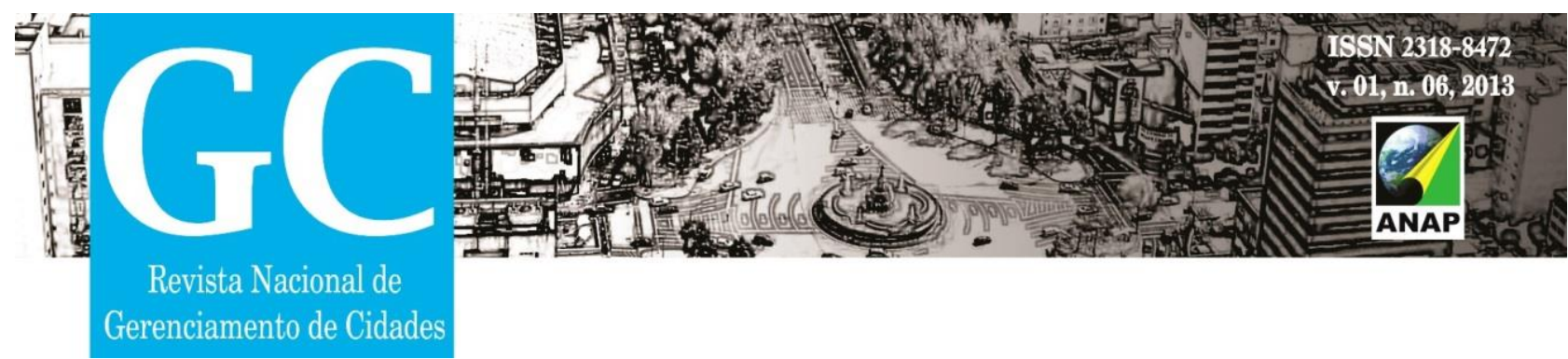

Sugestão de ação mitigadora: É indiscutível que a presença de árvores nos cemitérios é benéfica principalmente pelo seu valor indireto ${ }^{7}$, porém, como todo ser vivo, elas possuem uma durabilidade e são suscetíveis a pragas e doenças em seu ciclo de vida.

Foi constatado na vistoria que várias árvores estão em péssimo estado fitossanitário, carecendo de supressão, bem como poda, para ajuste do fuste. Seria pertinente ampliar a equipe que realiza o monitoramento das espécies arbóreas e iniciar um processo de substituição das espécies do cemitério por espécies com raízes pivotantes, a fim de evitar invasões de futuros jazigos, destruição do piso e túmulos ou danos às redes de água, de esgoto e drenagem.

\section{- Alagamento no lóculo e erosão laminar}

Problema: durante a vistoria, foi constatada erosão laminar escoando em direção ao fragmento existente nos fundos do cemitério.

\footnotetext{
${ }^{7}$ Valor de uso indireto representa o benefício atual do recurso, derivado de funções ecossistêmicas como, por exemplo, a proteção do solo, a estabilidade climática e a proteção dos corpos d'água.
} 
Revista Nacional de Gerenciamento de Cidades, v. 01, n. 06, 2013, pp. 28-41
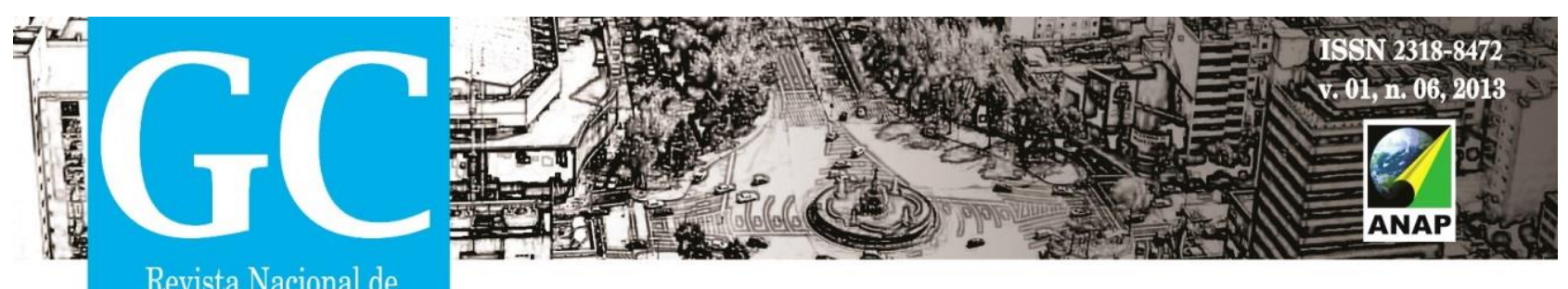

Revista Nacional de

Gerenciamento de Cidades

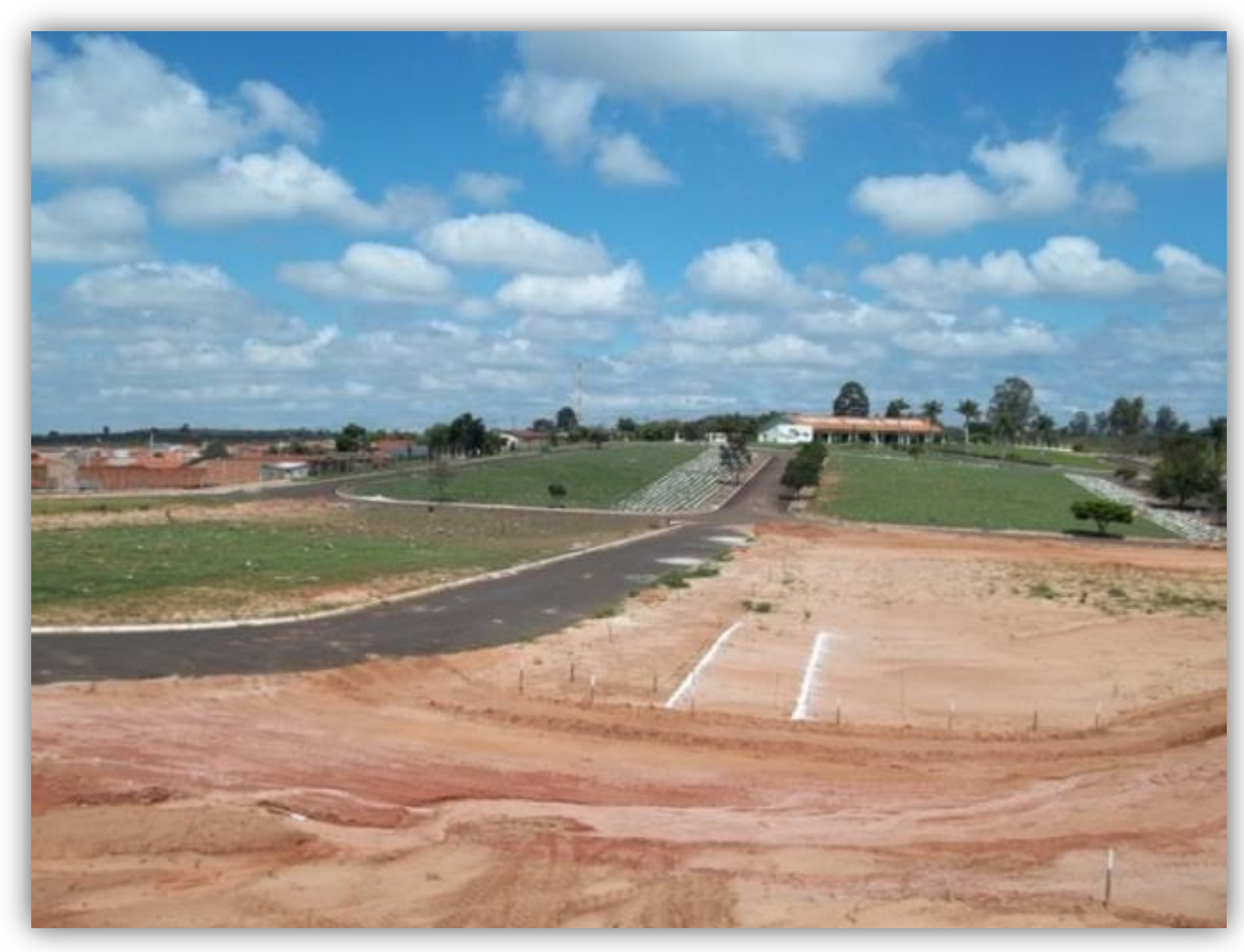

Figura 4 - Erosão Laminar 
Revista Nacional de Gerenciamento de Cidades, v. 01, n. 06, 2013, pp. 28-41
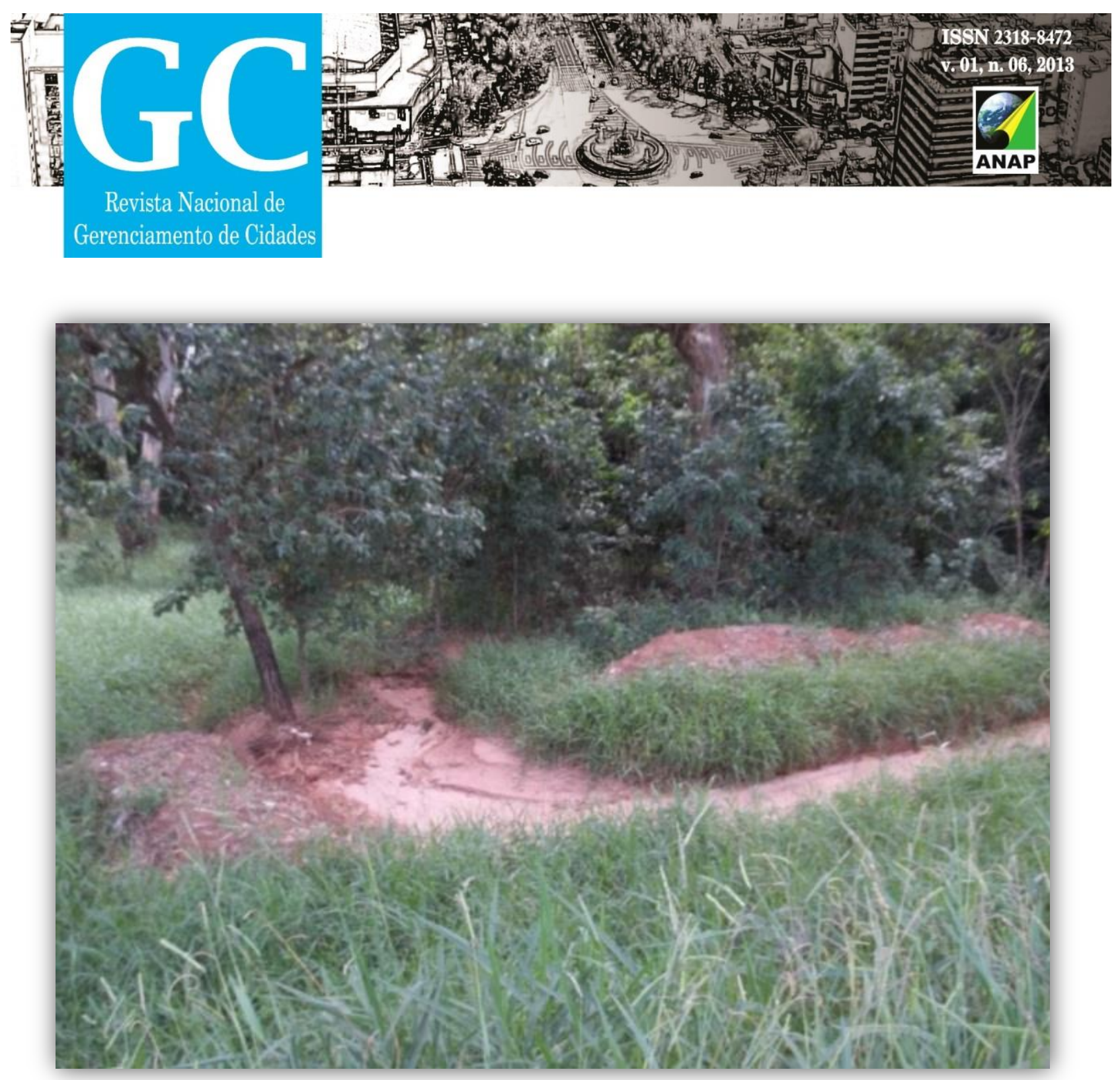

Figura 5 - Erosão Laminar 

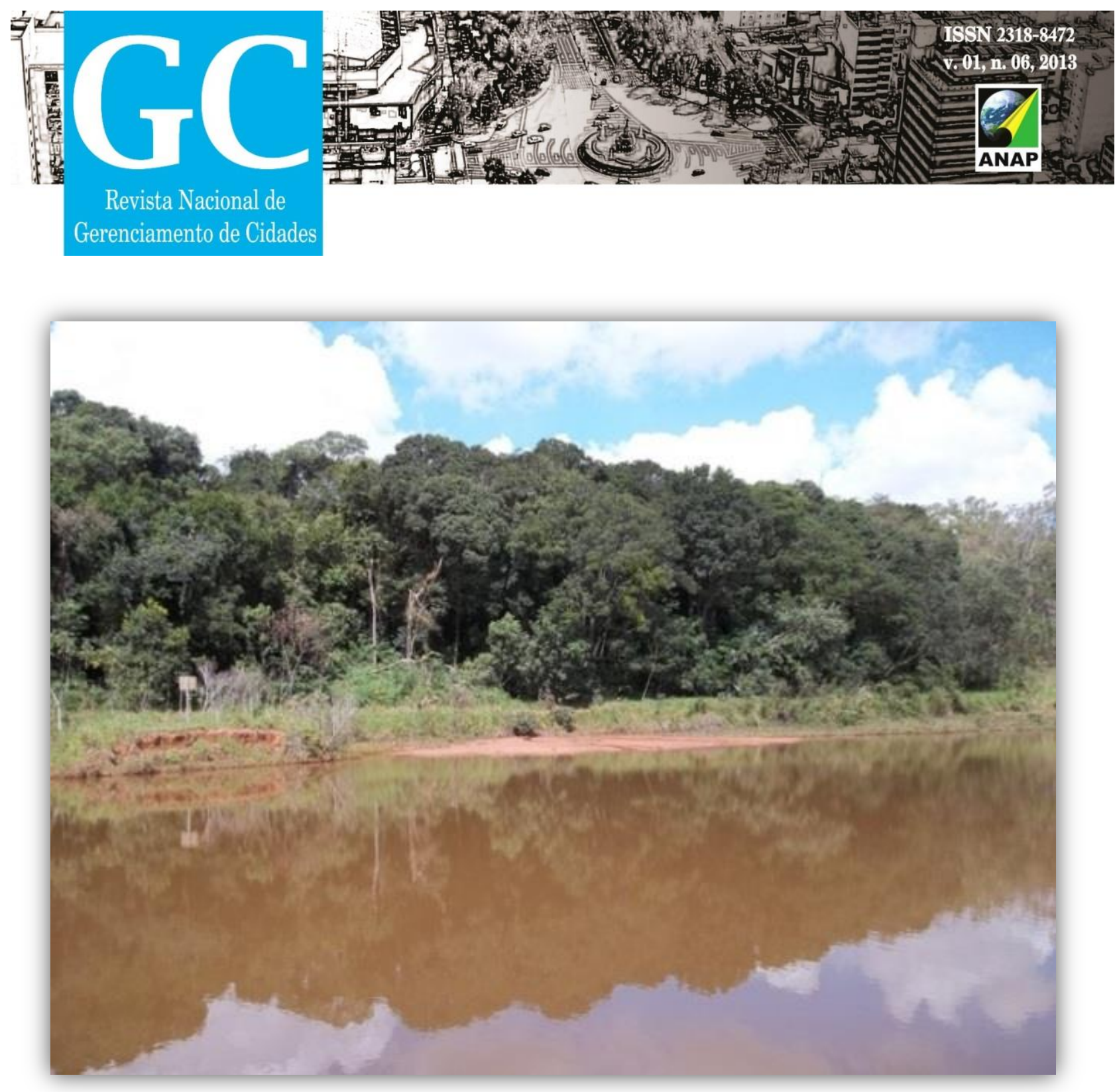

Figura 6 - Destino do carregamento de partículas.

Campos (2007) relata que, "dependendo das condições de estanqueidade e confinamento, o necrochorume seca naturalmente, polimeriza-se, reduz a pó e não permeia para o solo circunvizinho. Mas se ocorrer existência de água/umidade no local, facilita o escoamento do mesmo". Assim, existe a possibilidade da água em questão estar contaminada. Em consonância, Matos (2001) relata que "pode ocorrer o consequente extravasamento do produto da coliquação para a superfície, o qual acaba por escoar nas calçadas e ruelas do cemitério onde circulam pessoas e animais". 


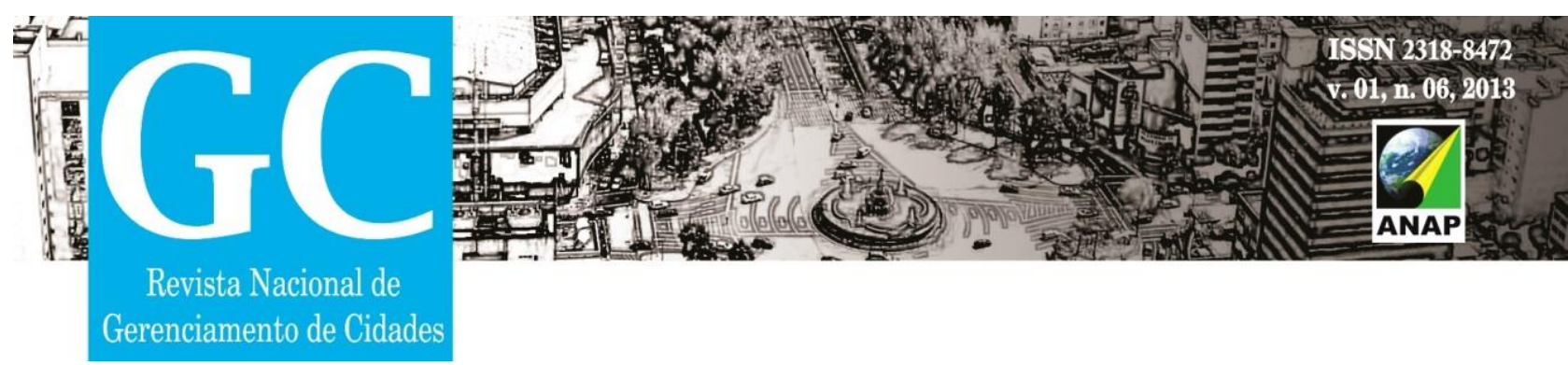

Essa inferência sobre a contaminação dessa água pode ser mais bem explicado segundo Cappucci (2001 apud NASCIMENTO, 2009, p. 20), que descreve dois tipos de fonte de poluição:

a) a fonte localizada (ou pontual), responsável pelo lançamento de poluentes em um determinado local, que é fácil de identificar e de monitorar e

b) a fonte difusa (ou não localizada), que envolve o lançamento dos poluentes sem um ponto de referência, espalhando-os por toda a área, que é difícil de identificar e tratar.

Dentre as fontes de poluição e contaminação da água, destacam-se aquelas capazes de atingir as águas subterrâneas, pelo potencial estratégico que estas terão na manutenção da vida. São elas:

i) Infiltração das fossas sépticas;

ii) Injeção de esgoto no subsolo;

iii) Vazamento de tubulações ou depósitos subterrâneos;

iv) Infiltração de águas contendo agrotóxicos, fertilizantes, detergentes e poluentes atmosféricos depositados no solo;

v) Percolação do produto da coliquação resultante de depósitos de lixo no solo e

vi) Percolação do produto da coliquação resultantes dos cemitérios".

De acordo com Campos (2007 apud SILVA, 2000), "em função da viscosidade e densidade do necrochorume em relação à água, formam-se plumas de contaminação que podem se disseminar pelo solo saturado, com velocidade variável, e atingir distâncias significativas a partir da origem". É importante ressaltar que a contaminação das águas subterrâneas pode se dar pelos cemitérios, mas também é causada por lixos e outras fontes de resíduos (Pacheco, 1995). Segundo Silva (2000), "dependendo da profundidade do lençol freático, a carga microbiológica do necrochorume (vírus e bactérias) é eliminada e não existem problemas de contaminação". 

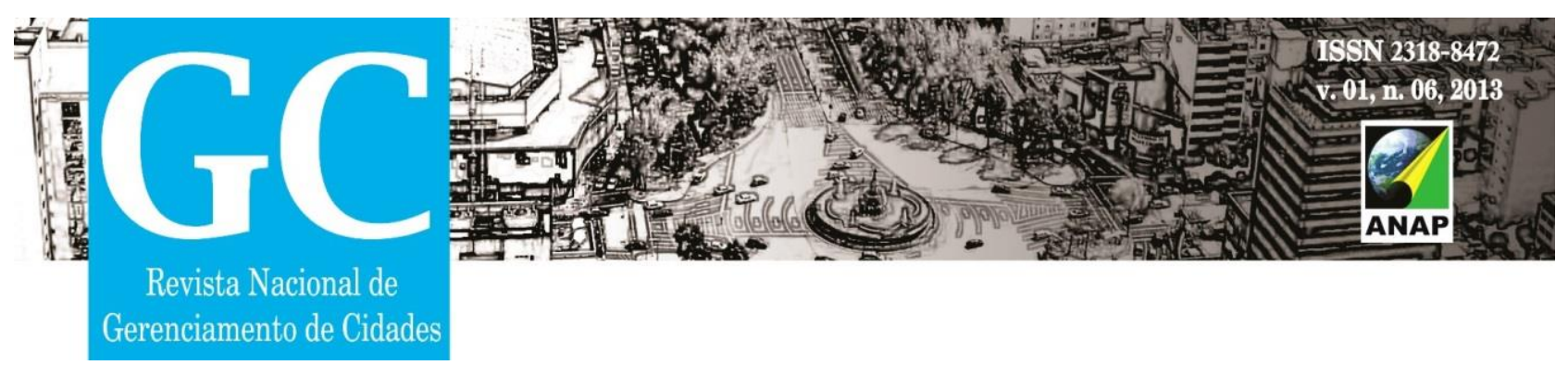

Outro fenômeno importante a ser descrito é o retardamento no processo de decomposição dos corpos sepultados diretamente no solo. Isso ocorre normalmente devido a interferências externas em determinadas condições geológicas, e é observado em um grande número de cemitérios. Os fenômenos conservativos mais comuns são a saponificação e a mumificação (Pacheco; Batello, et al.; 2000; apud Nascimento, 2009).

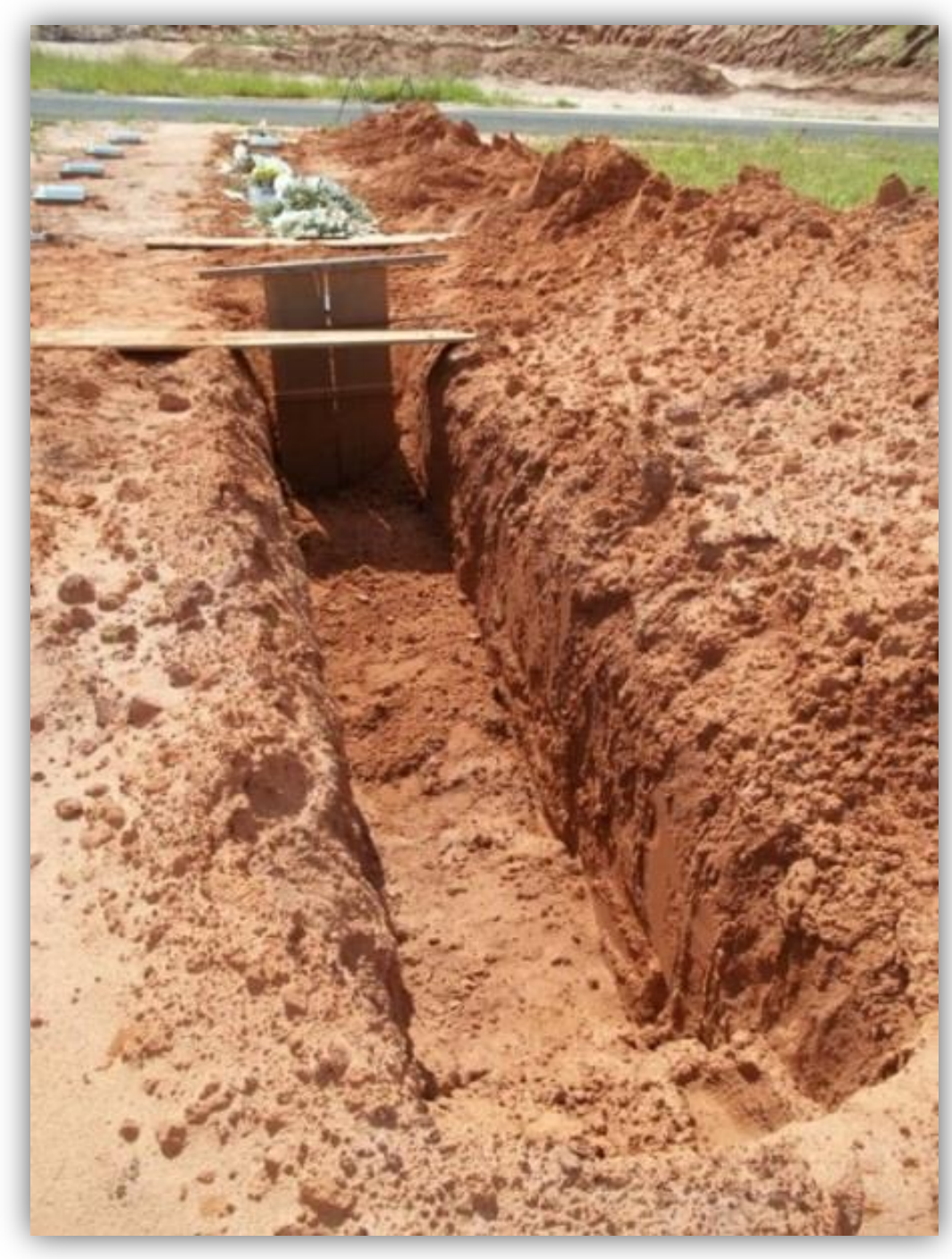

Figura 7 - Lóculo pronto para receber sepultamento. 


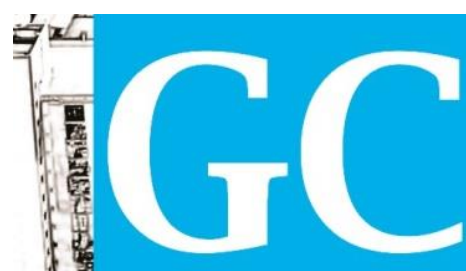

Revista Nacional de

Gerenciamento de Cidades

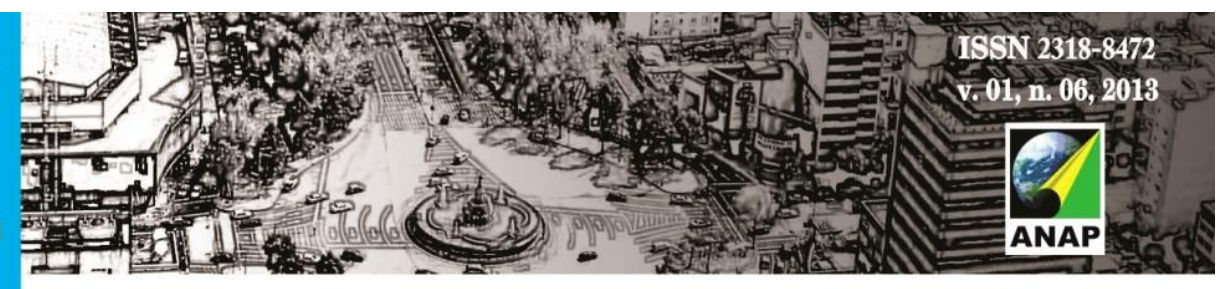

Segundo Nascimento (2009), a mumificação ocorre geralmente em ambientes onde predominam baixa umidade e temperatura elevada, o que impede a ação microbiana. Os solos que propiciam a mumificação são os do tipo arenoso das regiões desérticas e os solos calcários (permitem a histometabase, uma fossilização incipiente provocada pela substituição catiônica do sódio e do potássio pelo cálcio). Se o ambiente for excessivamente úmido, há o favorecimento da saponificação, em que a gordura adquire um aspecto céreo. Este processo ocorre mais facilmente em solos argilosos, porosos, impermeáveis ou pouco permeáveis, quando saturados de água. Ambos mumificam e saponificam, prolongando a permanência dos corpos semi-decompostos, e mantêm o perigo de contaminação latente, dada a oferta de vetores disponíveis e mobilizáveis.

No caso em questão, possivelmente as águas encontradas dentro dos lóculos são oriundas do escoamento das águas pluviais que infiltram no solo, uma vez que em nenhuma outra área do cemitério é visível o afloramento de água.

Sugestão de ação mitigadora: a informação mais importante para a implantação de cemitérios é a profundidade do topo do aquífero, ou seja, o nível hidrostático, pois é exigida uma distância mínima do nível inferior das sepulturas ao topo do lençol freático. $\mathrm{O}$ CONAMA, por meio do artigo $5^{\circ}$ da resolução 368 de 28 de março de 2006 (CONAMA, 2006 / Nascimento, 2009), exige que essa distância seja de pelo menos um metro e meio acima do mais alto nível freático, medido no final da estação das cheias.

Seguindo essa linha, recomenda-se a implantação de poços de monitoramento de acordo com a norma NBR 13.895 da ABNT (1997), com a finalidade de monitorar a carga hidráulica do aquífero livre, bem como a quantidade de água subterrânea. Caso ocorram indícios de contaminação, as amostras dos poços deverão ser analisadas seguindo os parâmetros de qualidade da água estabelecidos na Portaria n 1469/2000 do Ministério da Saúde. 


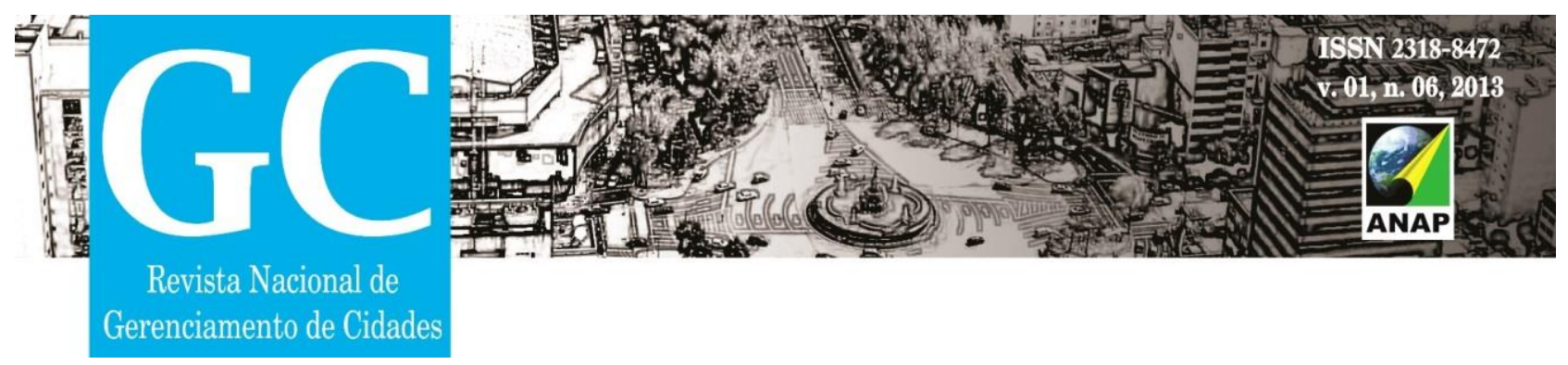

A escolha da localização poderá ser definida através de estudos eletromagnéticos, em que as áreas de maior condutividade elétrica serão escolhidas para implantar os poços (Matos, 2001). Medidas preventivas, como a utilização de substâncias oxidantes nos sepultamentos (óxido de cálcio anidro ou peráxido de cálcio) e a adoção de laje no fundo das sepulturas com depressão para coletar o necrochorume oriundo dos cadáveres, também devem ser adotadas.

Quanto aos processos erosivos, devem-se planejar canais de escoamento direcionados a um estanque de tratamento, pois as águas pluviais devem ser tratadas antes de serem lançadas no sistema de esgoto.

\section{CONCLUSÃO}

Este estudo tem a pretensão de nortear futuros estudos no processo de regularização ambiental do cemitério em questão, comentando medidas mitigadoras a serem implantadas. É pertinente incluir que o pragmatismo não deve nortear todos os temas existentes no empreendimento, uma vez que o assunto envolve sentimentos dos familiares que utilizam o serviço funerário.

O cemitério Jardim foi construído a 125 metros da nascente de um dos principais rios da cidade de Botucatu, o Rio Lavapés. Tal escolha exibe a falta de informação existente no período da sua implantação, pois o cemitério encontra-se à montante da nascente, facilitando assim a percolação dos compostos.

No estudo preliminar foi constatado contaminação das águas superficiais. Esse é um forte indício de uma possível contaminação do lençol freático, onde a recomendação será utilizar uma solução de ácido peracético, formada de ácido acético, peróxido de hidrogênio e estabilizante, nos poços de monitoramento hidrogeológico.

Não foi contemplado estudo preliminar, mas seria de suma importância realizar sondagens abaixo da área em que os caixões são enterrados. De acordo com a CONAMA 


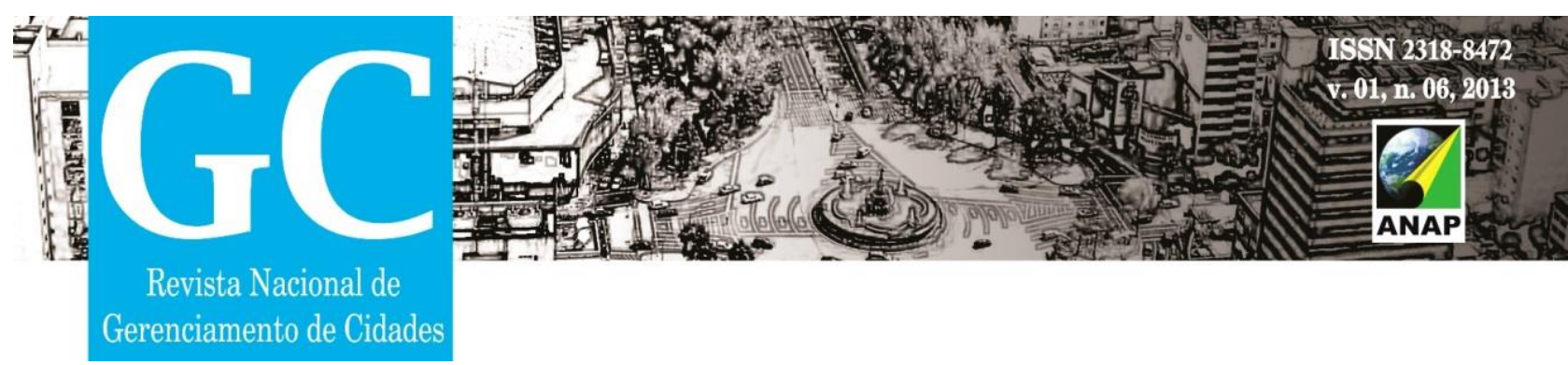

420/2009, os caixões devem ser enterrados a $1,5 \mathrm{~m}$ abaixo do solo. Portanto, sugerimos que as sondagens sejam subsuperficiais, superiores a $1,5 \mathrm{~m}$, conforme Manual de Gerenciamento de Áreas Contaminadas, da CETESB. O monitoramento da qualidade do solo através de sondagens servirá para verificar as possíveis ocorrências de vazamentos de produto de coliquação (necrochorume ou liquame funerário) ou outras substâncias provenientes da atividade do cemitério no solo.

\section{REFERENCIAL}

ASSOCIAÇÃO BRASILEIRA DE NORMAS TÉCNICAS. NBR 10.004: resíduos sólidos: classificação. Rio de Janeiro, 1987.

Bolivar Matos \& Alberto Pacheco - A avaliação da ocorrência e do transporte de microrganismos no aquífero freático do cemitério de vila nova cachoeirinha, município de São Paulo - XII Congresso Brasileiro de Águas Subterrâneas - 2001

CAMPOS APS. Avaliação do potencial de poluição no solo e nas águas subterrâneas decorrente da atividade cemiterial [dissertação de mestrado]. São Paulo: Faculdade de Saúde Pública da USP:2007.

CAPUCCI, Egmont; MARTINS, Aderson Marques; MANSUR, Kátia Leite; MONSORES, André Luiz Mussel. Poços tubulares e outras captações de águas subterrâneas: orientação aos usuários. Projeto PLANÁGUA-SEMADS/GTZ. Rio de Janeiro: Secretaria de Estado de Meio Ambiente e Desenvolvimento Sustentável - SEMADS e Departamento de Recursos Minerais RJ, 2001. [2 e 9]

KEMERICH, P. D. C.; SILVA, J. L. S.; BARROS, G.; BORBA, W. F.; UCKER, F. E.; FOLETTO, C. V. Caracterização química da água subterrânea em área ocupada por cemitério: uso da técnica de espectrometria de fluorescência de raios-X por energia dispersiva (EDXRF). Ambi-Agua, Taubaté, v. 7, n. 3, p. 166-182, 2012.

KEMERICH, P.D.C.; SILVA, P. R. B.; de Borba, W. F.; GERHARDT, A. E.; FLORES, C. E. B. Alteração Química em Solo Ocupado por Necrópole em Seberi - RS. In: 26ํㅡㄹ Congresso 


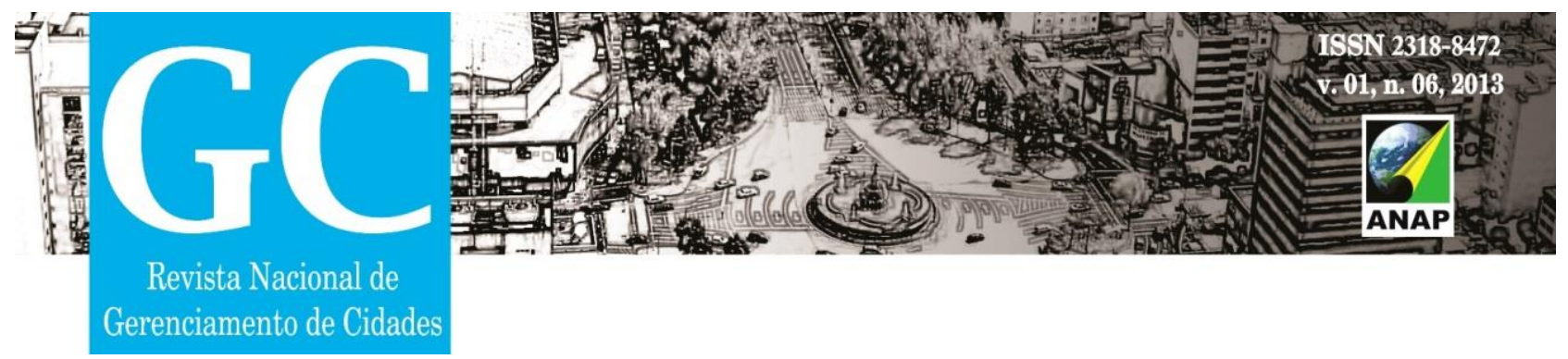

Brasileiro de Engenharia Sanitária e Ambiental. Porto Alegre - RS, Anais, VI- 159, setembro de 2011.

KEMERICH, P. D. C.; Descovi Filho, L. L. V.; UCKER, F. E.; FOLETTO, C. V. Influência Dos Cemitérios Na Contaminação Da Água Subterrânea Em Santa Maria - RS. Águas Subterrâneas, v.24, n.1, p.129-141, 2010.

KEMERICH, P. D. C. - Influência Dos Cemitérios na Contaminação da Água Subterrânea em Santa Maria - RS - Águas Subterrâneas, v.24, n.1, p.129-141, 2010.

MATOS, B. (2001) Avaliação da ocorrência e do transporte de microrganismos no aqüífero freático do cemitério de Vila Nova Cachoeirinha, município de São Paulo. São Paulo, 114 p. Tese (Doutorado)- Instituto de Geociências, Universidade de São Paulo.

MINISTÉRIO DA SAÚDE (2001) Portaria no. 1.469, de 29 de dezembro de 2000. Estabelece os procedimentos e responsabilidades relativos ao controle e vigilância da qualidade da água para consumo humano e seu padrão de potabilidade, e dá outras providências. Diário Oficial da República Federativa do Brasil, Brasília, DF, 19 jan. 2001. $22 \mathrm{p}$.

Occhipinti, A.G. e P. Marques dos Santos, 1965: Análise das máximas intensidades de chuva na cidade de São Paulo. Publicação IAG USP. 41pp.

PIRES NETO, A.G. As abordagens sintético- histórica e analítico- dinâmica, uma proposição metodológica para a geomorfologia. Tese de Doutoramento. Departamento de Geografia - Universidade de São Paulo, São Paulo.302 p., 1992

PACHECO, A.; BATELLO, E. (2000) A influência de fatores ambientais nos fenômenos transformativos em cemitérios. Revista Engenharia e Arquitetura, v.2, n. 1, p. 32-39.

PACHECO, A.; MENDES, J.M.B.; MARTINS, T.; HASSUDA, S.; KIMMELMANN, A.A. (1991) Cemeteries - a potential risk to groundwater. Water Science and Technology, v. 24, n. 11 , p. 97-104.

PACHECO, A.; SILVA, L.M.; MENDES, J.M.B.; MATOS, B.A. (1999) Resíduos de cemitérios e saúde pública. Revista Limpeza Pública, v. 52, p. 25-27.

PACHECO, A. Os cemitérios como risco potencial para as águas de abastecimento. Revista Sistema de Planejamento para a Administração Metropolitana. Ano 4, n. 17, 1986.

PACHECO, A. Cemitério e meio ambiente [tema de livre docência].São Paulo, Instituição de Geociências da USP; 2000. 

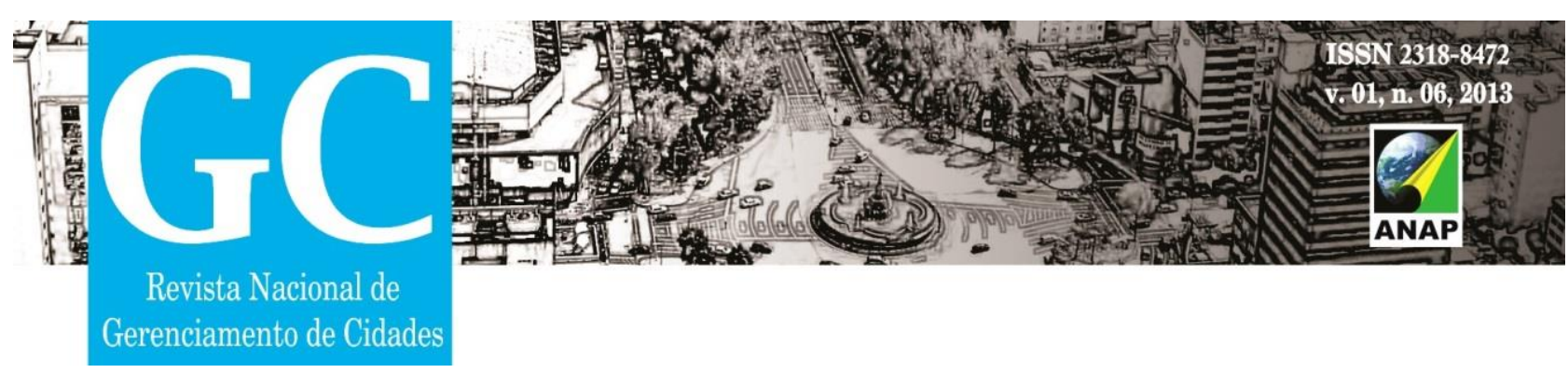

PAIVA, J. B. D. e PAIVA, E. C. D. Hidrologia Aplicada à Gestão de Pequenas Bacias Hidrográficas. 2001. 625 p. RIBEIRA, F.

NORMA TÉCNICA. L1.040. Jan/1999. 6 PÁGINAS. Implantação de cemitérios. Companhia Ambiental do Estado de São Paulo.

RESOLUÇÕES DO CONAMA. RESOLUÇÃO CONAMA nํ 358, de 29 de abril de 2005. Publicada no DOU no 84, de 4 de maio de 2005.

Resolução CONAMA № 420/2009 - "Dispõe sobre critérios e valores orientadores de qualidade do solo quanto à presença de substâncias químicas e e estabelece diretrizes para o gerenciamento ambiental de áreas contaminadas por essas substâncias em decorrência de atividades antrópicas.

ROMANÓ, E. N. L. Cemitérios: Passivo ambien-tal, medidas preventivas e mitigadoras. Disponível em: <http://www.sobrade.com.br/even-tos/20 05/visi n rad /palest ras/el ma romano_cem i-terio.pdf> Acesso em 05 de setembro de 2009.

Ueda SMY, Comparação entre a microbiota da terra nos cemitérios: locais virgens e locais onde são enterrados corpos. Arq Med Hosp Fac Cienc Med Santa Casa São Paulo. $2011 ; 56(2): 74-91$ 